\title{
Research on Application-Oriented Talent Training Mode of Private Undergraduate University
}

\author{
Jiangbo Chen \\ Qingdao Huanghai University \\ Qingdao, Shandong, China \\ jiangbochen1981@163.com \\ Shixian Zeng \\ Qingdao Huanghai University \\ Qingdao, Shandong, China
}

\author{
Yan $\mathrm{Li}^{*}$ \\ Qingdao Huanghai University \\ Qingdao, Shandong, China \\ liyanvsl@126.com \\ Shaoqing Wang \\ Qingdao Huanghai University \\ Qingdao, Shandong, China
}

\begin{abstract}
The present study describes the private undergraduate university transition development background, analyzing training applied talents, characteristics and typical patterns. By taking Qingdao Huanghai University as an example, explores problems during the transformation regarding curriculum establishment, industry-education cooperation, teaching, and faculty team, and etc. Thus the paper puts forward some transformation suggestions and builds a pattern in the process of restructuring and development of application-oriented training model. A school-based education system needs to be established by giving the school enough decision-making power; the government should give more policy support; the enterprises and the school should establish a long-term cooperation system; the transformation of school talent training system should focus on curriculum establishment, forging an all-around teaching system and establishing a double-identity teacher team.
\end{abstract}

Keywords-private undergraduate universities, applicationoriented Talent Training, training Mode, The construction of teacher's team

\section{INTRODUCTION}

After three decades of exploration and development, nongovernment higher education in China has initially formed its own school-running level, characteristics and discipline structures. Especially in the last decade, non-government education achieved a great leap from scale-oriented expansion to connotation-oriented development, which made tremendous contributions to the popularization of higher education in China In the year of 2015, Ministry of Education issued guidance on the transitional development of the local universities or colleges, which should practice the reform of applicationoriented technology [1].

Application-oriented university is a new type of college and university which make the undergraduate education as the main body, applied talents cultivating as the goal and the service offer of local economy or industry as its purpose. According to the training target of Applied Undergraduate universities, high level of practicality, skilled and occupational professional students should have strong practical ability, rich knowledge base on this area, strong learning and adapting ability, high sense of innovation and good comprehensive quality.

The private undergraduate university transition development is a major country strategy in recent years on higher education. It is very important to research the restructuring and development and the training model of applied talents, to adapt to economic and social transformation, to serve the local economic development, to improve their educational quality, to cultivate applied talents.

\section{ACCURATE POSITIONING OF PERSONNEL TRAINING OBJECTIVES}

The results of investigation and analysis show that: domestic manufacturing supply lack of application-oriented talents, part of the private undergraduate university vague idea of orientation and development, disciplines and market demand are low matching degree; application personnel training problems include training objectives and process of dislocation theory and practice of teaching confuse, lack of pluralism training quality evaluation indicators. Undergraduate emphasizes on cultivating high-quality and applied versatile talents who can design, develop and run engineering projects, while feeling equal to management and marketing of production field, etc, a series of work.

By the theory of overall strategic and mal-position competes, the strategic planning has been proposed for Qingdao Huanghai University from 2010-2020. The strategy implement to reach the goal of overall strategic planning has been given too. According to the overall strategic planning, the strategic plans have been analyzed: Strategy of Industry-AcademyResearch, Faculty development strategy, Talent training strategy. Industry-Academy-Research for UAS is different from Chinese research universities in serving society: smallmiddle cities and enterprises. From such kind of IndustryAcademy-Research, the university find its position, by which made contribution for development of economic in the small cities and enterprises and found the platform for training applied talents [2]. The last one is strategy of technical 
undergraduate, which is different from higher vocational teaching and academic undergraduate. The principle for technical undergraduate given is "A solid foundation, broad extension, strong ability, attention to the application", which focus on personal lifetime development by general education and quality education, employment ability by major education through strategic alliance between UAS and enterprises. The system of Chinese Universities of applied sciences should be established by the special strategy for UAS.

\section{ADJUST SPECIALTY CONSTRUCTION ACCORDING TO LOCAL CHARACTERISTICS}

Analyzes and summarizes the training mode of applied talents in private undergraduate universities, pointing out its problems include: ambitious convergence, personnel training specifications homogenization, he establishment of the cluster overlap, professional coverage small, curriculum and professional standards convergence is not strong, the teaching process and the production process disjointed, personnel quality evaluation main single, quality evaluation of the content and application-oriented direction discrepancy. From the micro perspective, competency-oriented schools should clearly applied talents training objectives, based on market demand, flexible set of professional and professional clusters, convergence professional standards, improving the scientific curriculum and teaching system [3].

Qingdao Huanghai University is a public welfare school, tuition is the economic foundation of running a school. Taking into account the input and output, we take the following measures to deal with the problems of disciplines and specialties which poorly enrolled and employed in recent years. For that occasional depression specialties, carefully study the market demand, intensify reform efforts to change the passive situation as soon as possible; For that intermittent depression specialties, can adopt the method of annual enrollment, so as to give out teaching resources to the prosperity specialties, this can reduce the pressure of employment; for that persistent depression specialties, can be closed and revoked. According to the specific needs of enterprises, professional application ability should focus on occupation ability, applied technology university should focus on cultivating students' technical skills, the professional application ability needs to be refined into the professional post ability, to improve the professional application ability, and to adapt to the pertinence and practicability of the professional position.

\section{STRENGTHEN THE CONSTRUCTION OF TEACHING STAFF}

The study shows that there are certain problems in professional capacity of the private undergraduate university teachers, mainly for the following five aspects: First, the trend of teachers' structure are getting younger and younger, too few teachers have business working experience; second, teachers are lack in practical ability, cooperation between schools and enterprises exists multiple obstacles; third, academic researches of teachers separate with the market practice, teachers are insufficient in scientific practical ability; fourth, deviations exist in the awareness of social services of university teachers, government policy and evaluation mechanism are partly dislocated; finally, the transformation initiative of teachers in the private undergraduate university are not strong, they are lack of motivation and selfdevelopment ability.

Through thoroughly analysis of these problems, we find the reasons behind the professional capacity of private undergraduate university teachers are diverse, firstly the lack of related policy support and financial support affect the improvement of teachers' professional competence; secondly, the shortage of school-enterprise cooperation policy in private undergraduate university and the insufficiency of depth and breadth in school-enterprise cooperation mode hinder the development and promotion of teachers' professional capacity; Again, congenital deficiency of local undergraduate is one of the reasons which impede the development of teachers' professional ability; In addition, private undergraduate university incentive evaluation mechanism and evaluation system are not reasonable which also affects the professional development and upgrade of teachers; finally, the insufficiency of source and promotion of private undergraduate university teachers' independent development cause a lot of problems in improving teachers' professional skills.

Teachers' professional training should be carried out in many forms. Qingdao Huanghai University where the author works in uses a "five-layer formula" training strategy and supporting measures to improve teachers' skills. First, take advantage of the existing resources of the school training base to improve the basic skills. Second, using holiday time, through the way of hiring experts of companies and industry into the school, the school established professional training camp, so the professional theory and professional practice of the professional teachers can be promoted further. Third, arrange professional teacher to attend regularly scheduled professional learning and skills training, to dig deeply the frontier knowledge and the future development trend of each specialty. Fourth, to arrange teachers go to the businesses for a period of 2 to 3 months of testing and training during the school summer vacation. Teachers can master professional knowledge and skills, at the same time, get the knowledge and talent needs of jobs. Fifth, the technician identification, which asks teachers to attend the exam. The identification process of technicians and senior technicians is the assessment of the knowledge and skills that the teachers get in the previous four stages, but also a sublimation of the professional skills of teachers

Strengthen bilateral depth substantive cooperation between schools and enterprises, and take the road of integration research. Encourage teachers to declare research projects with businesses, and participate in project design, to find comprehensive graduation practice from the production practice for the students. To encourage teachers to go out of school, to be business-oriented and production-oriented, to undertake research projects actively, to engage in scientific research and technical services, to study technology in-depth, to research and develop new products and new technology. To encourage teachers to carry out various types of external professional and technical development services [4]. 
Advantages of combination of research: First, to achieve the combination of the research work and teaching, this helps teachers in teaching innovation, and exploring ways to solve problems, and improving the quality of teaching. Second, to carry out applied research and technical services through cooperation with enterprises, this improves the research capacity of teachers and the promotion of the use of scientific research. Third, to achieve the combination of teachers' scientific research work and the practical needs of business, and to achieve effective research transformation through the technology and equipment of professional teachers, which is conducive for energy conservation and improvement of product quality, development of new products, so as to serve the local economy and strengthen the willingness of companies' partnerships.

\section{ESTABLISH A COOPERATIVE PRACTICE TEACHING MECHANISM BETWEEN UNIVERSITY AND ENTERPRISE}

Cooperation between school and enterprise is the inevitable outcome of the development of science and technology, the representation of higher education to meet the demand of economical development and social produce combination ,as well as the certain choice of market economy and knowledge economy era .countries all over the world paid strongly attention on Cooperation between school and enterprise .In order to promote the deepen of vocational and technology education work, the State Council issue the decision of accelerating the development of modern vocation education in May of 2014. The guideline and target tasks as well as specific requirement of reform of modern vocational education has been put forward by The State Council. The reform of higher education has been come into a new stage. How to comply with the need of higher education reform and develop ,promote the training of practical talents ,meet the demand of market to the practical talents has become new proposition of the deepen reform of colleges and universities in this new developing environment.

By the research of the practice, considered the best choice for the path of entrepreneurial talent training in applicationoriented institutes is the combination of a connection with Government, Industry and University. By the building of practical training base, forming a model education with the combination of practical and theoretical, cultivating entrepreneurial talent with entrepreneurial spirit and ability, satisfying social needs, filling the vacancy talent, perfecting talent structure, solving the employment of university students by self-employed, while giving more people jobs and promoting the development of national development.

We sums up the factors influencing the integration of production and education three big actors, namely the government's policy, school and enterprise cooperation; the above influencing factors put forward the corresponding countermeasures are put forward. Which suggest departments should in terms of economy, system, coordination and supervision, support the fusion of the implementation of the production and education of applied undergraduate university and universities; School itself should improve the integration of production and education and strengthen the management team and the construction of teaching staff; Enterprise should be actively involved in the production of and college teaching integration tide, Enterprises actively participate in schoolenterprise cooper-action, the initiative to provide practical training bases and production technology, and promoentrepreneurial talent training[5]. In the process of Schoolenterprise cooperation, due to the difference between the standpoint of interests of both sides and cultural background, the teaching of practice is not concerned with the teaching of theory on talent training, so government need macro-control. By the promulgation of policy, enacting laws and strengthening the management, we build organizations or institutions of supervision and support; provide multiprotection institution; expanding cross industry regions, the sharing resource of industries and even national boundaries; broadening international vision; effectively carrying out the cooperation of international entrepreneurship education; better promoting the development of the mode of a connection with Government, Industry and University, so that entrepreneurial talent training application-oriented institutes become more international.

\section{IMPROVE THE PRACTICAL TEACHING SYSTEM}

Applied technology university teaching objectives not only confine to the acquisition of theoretical knowledge, but also focus on the students' Professional quality, investigation and practical ability and the consciousness of service and management, etc. Those illustrate the necessity of highlighting practical teaching, deepening the connotation of the practice teaching, enriching practical teaching method and strengthening practical teaching effect. Compared to lecture method of teaching, practice teaching is more intuitive and vivid, and more easily to stimulate the students' learning motivation. During practice teaching, the perception of working environment, the professional and career planning skills will be enhanced with the student's personal experiences [6].

according to the professional training goal , combined with professional teachers' recommendations the teaching and research section should formulate the course syllabus and examine outline of this major ;based on the syllabus , examine outline, and combined with the students' individuality, teachers should refine teaching objectives, determine the teaching contents, and design the learning plan together with student themselves ; introducing the Studio projects which devote to the teaching contents, and make sure the studios organize and manage these projects. The main line of whole teaching process follows practical works. The creation process is the learning process. Among the students in private undergraduate university currently, for the characteristics of We Chat, such as interesting and free of charge, using We Chat to expand the classroom and extend the teaching, build the mobile micro classroom between teachers and students is a new attempt. On the basis of We Chat, making use of fragmented time to carry out the mobile teaching model of combining We Chat and micro class, through the development, design and evaluation of the curriculum and platform, this paper proved that the effectiveness of mobile learning supported by We Chat, which improved the students' learning initiative, and promoted the education informationization. 
With a reasonable completed teaching system which composed and supported by a target system, a content system, a management system, and security system of the practical teaching which constructed by present situation of Higher Education of China. The main problem of higher education is how to cultivate new talents with innovation. The second class is regarded as the main position for training students' quality during the teaching practice in the higher education. Expanding and deepening the second class is being the objective condition to develop students' innovative capabilities in the operational system of college students' quality cultivation, and the important stage to cultivate and improve students' innovation and quality.

\section{SUMMARY}

This paper is based on the characteristics of students in private undergraduate university, school characteristics, combined with the current employment market demand situation, from the educational ideas, professional setting, curriculum system, teaching staff, practice teaching five aspects of the application oriented training mode reform, in particular, through the establishment of school entity, deepen cooperation between College and enterprise and other new practice teaching mode, deepen the training mode, so as to promote the development of private colleges and universities. analyzes the cannon problems of our private undergraduate universities in running a school based on the field surveys and other information on schools and puts forward the corresponding development and reform strategy combined with the actual school situation of Qingdao Huanghai University, and Proposes the practical and feasible solutions for other colleges and universities aiming at the common problems encountered in the process of running the school to promote the development of higher education in China.

\section{ACKNOWLEDGMENT}

This work was financially supported by the teaching reform research Projects of Vocational Education in Shandong Province(2017549), the teaching reform research Projects of Qingdao Huanghai University(2016jiaoxue06).

\section{REFERENCES}

[1] Wang Yang.A Study on the Training Mode of Applied Undergraduate Talents[J]. Technology and Innovation Management,2016(3):340-343.

[2] Liu Xiaoxiao.Probe the mode of talent cultivation in private undergraduate colleges[J].Journal of Baoji University of Arts and Sciences(Social Sciences),2015(6):237-240.

[3] Liu Yanjia.Study on Practice Teaching Innovation in New Applicationoriented Institutes[J].Journal of Shangqiu Vocational and Technical college, 2015(2):70-72.

[4] [2008] No.5 teach high "on the issuance of the Ministry of Education Personnel in Higher Vocational Colleges evaluation project notice"

[5] Li Mengqing Zhang Bizhu. "Double Type" teachers' team construction system of the review and reflection [J].Journal of education and profession, 2013(6):270-273

[6] Li Tao.Cultivation of innovative practice ability training of college students based on electronic design competition [J].Wireless Internet Technology,2016(17):80-81 